\title{
Rozvíjení environmentálních postojů z pohledu učitelů na 2. stupni základních škol
}

\author{
Jan Bartoš, Tomáš Matějček
}

Envigogika 10 (2) - Recenzované články/ Reviewed Papers

Publikováno/Published dne 2. 9. 2015

DOI: $\underline{10.14712 / 18023061.475}$

\begin{abstract}
Abstrakt
Příspěvek shrnuje výsledky původního výzkumu zaměřeného na problematiku environmentálních postojů. Jednalo se o kvalitativní výzkum, který byl proveden metodou polostrukturovaných rozhovorů a zúčastnilo se ho 10 respondentů (učitelů), kteři vykonávají funkci koordinátora EVVO. Otázky byly zaměřeny na chápání pojmů postoj, názor, hodnota a zájem. Bylo zjištováno, zda respondenti svou výuku cíleně zaměřují na rozvoj environmentálních postojů a jakým způsobem postoje u žáků rozvíjí. Na základě analýzy rozhovorů Ize respondenty rozdělit do několika skupin podle několika kritérií (především zda o postojích přemýšlejí v rovině teoretické a do jaké míry své závěry uplatňují v praxi). Dále bylo zjištováno, jaký vliv na výuku postojů sehrálo zavedení RVP. Většina respondentů se domnívá, že zavedení tohoto dokumentu príliš neovlivnilo rozvoj postojů ve výuce. Ve výzkumu byl také zjištóván vzájemný přenos postojů mezi žáky a jejich rodiči, přičemž byl zaznamenán především přenos postojů ze žáků na jejich rodiče.
\end{abstract}

\section{Klíčová slova}

environmentální postoj; koordinátor EVVO; environmentální výchova; rámcový vzdělávací program; kvalitativní výzkum

\begin{abstract}
This paper summarizes the results of original research focused on the issue of environmental attitudes. It concerns qualitative research which has been conducted by semistructured interviews with 10 respondents (teachers) who are environment education coordinators. Questions were focused on their understanding of the concepts of attitude, beliefs, values and interest. It also ascertained whether respondents considered their teaching systematically focused on the development of environmental attitudes and how they develop the attitudes of pupils. Based on an analysis of the interviews the respondents can be divided into several groups according to several criteria (primarily whether they think about attitudes at a theoretical level and to what extent their plans are put into practice). What impact the introduction of the Framework Educational Programme for Basic Education had on the teaching of attitudes was also observed. Most respondents believe that the introduction of this document does not significantly affect the development of attitudes in teaching. The transfer of attitudes between pupils and their parents was also
\end{abstract}


observed in which the predominant transmission of attitudes was from pupils to their parents.

\section{Key words}

Environmental Attitude; Coordinator of Environmental Education; Environmental Education; Framework Educational Programme for Basic Education; Qualitative Research 
Cílem tohoto př́spěvku je shrnout výsledky výzkumné sondy provedené mezi učiteli, kteří zastávají funkci koordinátora environmentální výchovy, vzdělávání a osvěty (dále jen EVVO) na základní škole. Výzkum byl proveden formou polostrukturovaných rozhovorů $\checkmark$ průběhu roku 2014 a bylo do něj zahrnuto 10 učitelů. Respondenti byli vybráni náhodně, přičemž všichni vyučují $v$ Praze nebo ve Středočeském kraji. Bližší charakteristika respondentů je uvedena v Př́loze 1.

Cílem výzkumu bylo získat informace o rozvoji environmentálních postojů na druhém stupni základních škol. Bylo zjišt́ováno, zda jsou respondenti schopni definovat tento pojem, jestli se svou výukou zaměřují na rozvoj environmentálních postojů a pokud ano, jakým způsobem tyto postoje ve své výuce rozvíjí. Pro vyhodnocování výsledků byly použity metody kvalitativního výzkumu.

Výzkumné otázky byly formulovány takto:

- Jak respondenti definují pojem postoj?

- Jaký význam přikládají environmentálním postojům ve své výuce?

- Jakým způsobem ve své výuce rozvíjejí environmentální postoje?

- Jak hodnotí učitelé zavedení RVP/ŠVP rozvoj postojů ve školní výuce?

- Zaznamenávají učitelé vzájemný přenos postojů mezi školou a rodinou?

Z výše uvedených výzkumných otázek vycházely konkrétní otázky v rozhovorech. Některé z nich byly v souladu s možnostmi kvalitativního výzkumu (Hendl 2005, Skutil et al. 2011, Švaříček \& Šed'ová 2007) mírně přeformulovány nebo upravovány během výzkumu, poslední z výše uvedených výzkumných otázek byla přidána po uskutečnění prvního rozhovoru, který poukázal na význam dotazovaného jevu.

\section{Definice pojmů}

Postoj vyjadřuje vztah jedince k určitému objektu či jevu (Průcha, Waltrová \& Mareš 1998, Kubiatko, Mrázková \& Janko 2011). Hayesová (2013) uvádí, že se jedná o naučenou predispozici k př́znivé nebo nepř́znivé reakci na určitý objekt, osobu či událost. Slaměník \& Výrost (2008, str. 250) definují postoj jako "relativně stabilní pripravenost jedince reagovat určitým zpưsobem na osoby, skupiny, situace, způsoby chování, předměty a názory. “ $Z$ výše uvedeného je patrné, že postoje mají hodnotící charakter a pomáhají jedinci s rozhodováním v nastalých situacích. Postoje mají svou vnitřní strukturu, která se skládá ze tří složek: kognitivní (názory a myšlenky k danému problému), emocionální (pocity a emocionální reakce k předmětu postoje) a konativní (behaviorální - tj. sklon k chování či jednání ve vztahu k předmětu postoje, Hayesová 2013).

I přesto, že postoje jsou relativně stabilní, tak dochází během života jedince $\mathrm{k}$ jejich postupnému vývoji, a to na základě získaných nových zkušeností a dalších podnětů z okolí (Hayesová 2013, Winter \& Koger 2009). Na proces formování postojů a okolností, které ho podmiňují, existují různé pohledy. Podle Fischbeinovy a Ajzenovy teorie (Fishbein \& Ajzen 1975 cit. in Hayesová 2013, Franěk 2008) se na formování postojů podílejí především získané informace a sociální prostředí, ve kterém se daný jedinec pohybuje (především rodina a sociální skupiny, jichž je jedinec členem a s nimiž se identifikuje). Právě sociální identita a sounáležitost $s$ některou sociální skupinou hraje při utváření postojů velmi důležitou roli. Ke změně postojů může dojít při tzv. "kognitivní disonanci“, kdy se setkají 
jedinci s odlišnými postoji. Pokud má jedinec $k$ určitému problému vyhraněný postoj, bývá často nepř́stupný novým argumentům, které by jeho postoj mohly ovlivnit. $V$ takové situaci může nové argumenty ignorovat prípadně napadnout jejich pravdivost anebo si účelově vybere část argumentů, které podporují jeho názor (Hayesová 2013). Pokud např́klad jedinci nezáleží na životním prostředí, pak jeho reakcí na "kognitivní disonanci" vyvolanou problémy, které se týkají životního prostředí, bude vytvoření nepravdivého, ale přesvědčivého vysvětlení svého chování a nedojde ke změně v jeho chování (Winter \& Koger 2009).

Postoje často bývají spojovány s pojmy názor, zájem a hodnota ${ }^{1}$. Nejedná se o synonyma, ale jednotlivé pojmy jsou ve společné interakci. Rozdíl mezi názorem a postojem je $v$ rovině emoční. Názory jsou většinou emočně neutrální. Jedná se o tvrzení nebo výroky o kterých si myslíme, že jsou pravdivé či nikoliv. Zájem, na rozdíl od postoje, představuje určitý typ motivace $k$ určité činnosti nebo objektu. Psychologický slovník definuje zájem jako "schopnost trvalejšího zaměření, soustředění na určitou věc s výrazným emočním doprovodem" (Hartl \& Hartlová 2000, str. 694). S postoji jsou silně provázány hodnoty, které vytváří základ samotným postojům. Hodnoty vyjadřují subjektivní míru důležitosti, kterou jedinec přikládá určitému jevu, věcem, chování, lidem atd. Představují "obecné kvality či objekty, kterých si ceníme" (Pastorová et al. 2011, str. 21.). Na základě hierarchicky uspořádaných hodnot si jedinec vytváŕí, svůj hodnotový systém, který se, stejně jako postoje, názory a zájmy, $v$ průběhu života mění, čímž se také mění chování jedince. Hodnoty jsou však relativně stálejší než postoje a vztahují se k více abstraktním pojmům (Hayseová 2013, Čáp \& Mareš 2001, Průcha, Waltrová \& Mareš 1998, Řehan \& Cakirpaloglu 2000).

Hlavní skupinou postojů, které se utvářejí prostřednictvím environmentálního vzdělávání, jsou postoje environmentální. Můžeme je chápat jako osobní přístup jedince ke konkrétním otázkám vztahu člověka k životnímu prostředí. Doporučené očekávané výstupy z EV uvádějí následující definici: „Environmentálními postoji rozumíme stanoviska, která žáci zaujímají k životnímu prostředí a jeho složkám, problémům, environmentální politice, technologiím, aktivitám apod.“ (Pastorová et al. 2011, s. 21) Podle Činčery (2007) jsou environmentální postoje jedním ze třech základních pilírư environmentální výchovy, spolu se znalostmi o životním prostředí a kompetencemi (způsobilostí) k jednání. Environmentální postoje mají u jedince probudit aktivitu, jejímž cílem je zlepšení životního prostředí (Tbilisi 1978). Vyjadřují míru znepokojenosti nebo lhostejnosti ve vztahu k životnímu prostředí a odrážejí ochotu změnit své chování ve prospěch životního prostředí (Rickinson 2001).

V koncepci př́rodovědné gramotnosti výzkumu PISA (ÚlV, 2006; Daniš, 2013), která vychází z pojetí struktury afektivní ${ }^{2}$ složky př́rodovědného vzdělávání podle Klopfera (1976), jsou environmentální postoje (pod označením odpovědnost vưči zdrojüm a životnímu prostředí) vyčleněny jako jedna $z$ kategorií postojů $\mathrm{k}$ prírodním vědám (jako další kategorie jsou vyčleněny zájem o prírodní vědy a uznání hodnoty vědeckého výzkumu).

\footnotetext{
${ }^{1}$ Tyto pojmy chápeme v souladu s Krajhanzlem (2010), včetně jejich ekvivalentů v angličtině - postoj (attitude), názor (belief), zájem (concern) a hodnota (value).

${ }^{2}$ Pro okruh cílů zaměřených na rozvoj určitých postojů a hodnot jedince bývá v české odborné literatuře používán výraz „afektivní. Vychází pravděpodobně z doslovného překladu anglického "affective". Takové označení může vyvolat určité nedorozumění, protože výraz "afekt" je v češtině synonymem pro nekontrolovanou emoci, a tu rozhodně nelze považovat za vhodný cíl vzdělávacího úsilí.
} 
Environmentální postoje jsou provázány s osobním vztahem člověka k přírodě, resp. $\mathrm{k}$ životnímu prostředí jako celku. Jako jeden $\mathrm{z}$ více aspektů vztahu $\mathrm{k}$ prrírodě chápe environmentální postoje Krajhanzl (2009). Podle něj Ize tento vztah definovat nejméně $\checkmark$ pěti základních rovinách (dimenzích). Těmito rovinami jsou: potřeba kontaktu s př́rodou, schopnost pro kontakt s prírodním prostředím, environmentální citlivost (senzitivita), ekologické vědomí a obecný postoj $k$ př́rodě. $z$ hlediska vzdělávacího procesu je důležité, aby rozvoj jednotlivých zmíněných rovin osobního vztahu člověka k přírodě probíhal ve vzájemné rovnováze.

Formování environmentálních postojů je dlouhodobý proces, který je u konkrétního jedince ovlivněn řadou faktorů (viz výše). Přestože školní vzdělávání hraje podle dosavadních výzkumů v tomto ohledu menší roli než např. vliv rodiny, volnočasové aktivity či osobní zkušenosti a prožitky, jeho význam je nezanedbatelný (viz např. Chawla 1999, Kulhavý 2009). Vedle osobnosti učitelů, která může být v řadě př́padů zásadní, hraje svou roli také celkové pojetí vzdělávání (vyplývající např. z kurikulárních dokumentů), použité učebnice aj. Z výzkumu, který provedli Eagels a Demare (1999) vyplývá, že mezi nejvýznamnější faktory, které u sledovaného vzorku žáků ovlivnily jejich environmentální postoje, patřilo rodinné prostředí, sledování prírodovědných filmů a četba knih o prrírodě.

Postoje patří do afektivní oblasti vzdělávacích cílů, která spolu s kognitivní a psychomotorickou oblastí vzdělávacích cílů tvoří základní strukturu učiva - výsledkem učení $v$ těchto třech oblastech jsou tzv. klíčové kompetence, které by si jedinec měl během studia osvojit. Kategorizací afektivních cílů se zabývali např. Anderson \& Kratwohl (2001) či Niemierko (1979). Obě kategorizace poukazují na etapy zvnitřnění určitých hodnot a postojů u žáků. Upozorňují, že přechod mezi jednotlivými taxonomickými úrovněmi vzdělávacích cílů není lineární, neprobíhá u všech žáků stejně a pro jejich rozvoj je nezbytná citlivá práce učitele (Fontana 1997, Kalhous \& Obst et al. 2002, Výzkumný ústav pedagogický 2007).

Rozvoj afektivních cílů je podle některých autorů obtížnější než rozvoj cílů kognitivních (viz např. Kalhous \& Obst et al. 2002). Tyto oblasti však nelze rozvíjet odděleně a je nutná jejich provázanost, které je dosaženo využitím vhodných metodických postupů. Petty (1996, s. 320) uvádí, že "afektivní učení je možné chápat jako kognitivní dovednost vyššího rádu". Rozvoj afektivních cílů je pomalejší, ale při dobré komunikaci v pedagogickém sboru se na jejich rozvoji může podílet více pedagogických pracovníků. Při jejich rozvoji je u žáků potřeba zapojit obě mozkové hemisféry (cit i rozum). Důležitou roli hraje i osobnost učitele, který by měl být pro žáky vzorem (Kalhous \& Obst et al. 2002).

Konkrétní okruhy (kategorie) environmentálních postojů a hodnot vymezuje Rámcový vzdělávací program pro základní vzdělávání (Výzkumný ústav pedagogický 2007, s. 100). Jedná se o kategorie postojů a hodnot, kterými přispívá průřezové téma Environmentální výchova k rozvoji osobnosti žáků.

Postoj jedince obvykle nezjistíme prímo, ale vyvozujeme ho $z$ jeho chování a jeho vyslovených mínění (Bechtel \& Churchman 2002, Jandourek 2001). Při hodnocení postojů je důležité rozlišovat postoje skutečné od postojů deklarovaných. Příkladem výzkumu, který byl zaměřen na zjištování rozdílu mezi deklarovanými proenvironmentálními postoji a skutečným spotřebitelským chováním je práce Činčery a Štěpánka (2007). Do výzkumu bylo zahrnuto 183 středoškolských studentů prvních a čtvrtých ročníků. Výzkum sledovaného vzorku respondentů ukázal, že u většiny z nich neodpovídá jejich spotřebitelské chování deklarovaným postojům. Rozpor mezi skutečnými a deklarovanými postoji může být způsoben náročností jednání, které z dané činnosti vyplývá. Pokud se jedná o méně náročné činnosti (např. třídění odpadu), může být rozdíl mezi deklarovanými a skutečnými postoji minimální, zatímco u náročnějších rozhodnutí resp. v prípadě rozhodnutí, která kladou na 
jedince větší nároky (např. volba mezi veřejnou dopravou a jízdou autem), bývá rozdíl mezi deklarovanými a skutečnými postoji výraznější (Bechtel \& Churchman 2002, Franěk 2008, Pfligersdorffer $1993^{3}$ cit. in Hromádka 2008, Winter \& Koger 2009).

Hodnocení environmentálních postojů se věnovala řada autorů. Výzkumy proběhly i v českém prostředí. Byly porovnávány různé skupiny respondentů (Matějček \& Bartoš 2012, Finnová 2010, Matějček 2010, Senčík 2009, Bezouška \& Činčera 2007). Do českého prostředí byly modifikovány i zahraniční verze evaluačních nástrojů - dotazníků. Na základě zjištěných výsledků bylo možné provést mezinárodní srovnání (Schmutzerová \& Bílek 2010). Franěk (2012) se pokusil změřit environmentální postoje pomocí překladu škály New Environmental Paradigm (Dunlap et al. 2000). Zřejmě nejrozsáhlejší hodnotící metodiku nejen pro environmentální postoje vypracoval Činčera (2013a, b, c). Zahraničních prací zaměřujících se na měření postojů je velké množství. Velmi často je jako měřící nástroj využit dotazník s touto metodou pracovali např. Mayer \& Frantz (2004), Schultz (2001), Dutcher et al. (2007), Clayton (2004), Lindstrom \& Johnsson (2003), Guagnano \& Markee (1995), Nisbet et al. (2009) a mnohé další. Měření postojů je prováděno $v$ řadě zemí po celém světě. Jako př́klad uved'me práce z těchto zemí: Nový Zéland (Kilbourne \& Polonsky 2005), USA (Powell et al. 2011), Malajsie (Said et al. 2007) Řecko (Dimopoulos \& Pantis 2003), Velká Británie (Kurz et al. 2007), Turecko (Tuncer et al. 2004, 2005), Švédsko (Jagers \& Matti 2010) a mnohé další.

\section{Metoda výzkumu}

Do provedeného výzkumu bylo zahrnuto 10 koordinátorů EVVO, jejichž základní charakteristika je uvedena $v$ Př́loze 1 . Při sběru dat, jejich vyhodnocování a následné interpretaci jsme postupovali podle etických principů pedagogického výzkumu, proto jsme respondenty a školy, na nichž působí, ponechali v anonymitě (Skutil et al. 2011).

Jelikož jsme chtěli získat informace o názorech, postojích a znalostech, zvolili jsme pro sběr dat metodu polostrukturovaného rozhovoru. Vzhledem $k$ tomu, že rozhovory vedli dva výzkumníci, bylo nutné pro kvalitnější vyhodnocování dodržovat stejný účel a osnovu rozhovoru a zároveň pro získávání dat byla vhodná velká pružnost celého procesu (Skutil et al. 2011, Hendl 2005). Tento typ rozhovoru umožňuje respondentovi, aby si vybral styl odpovědí, který mu vyhovuje (Ferjenčík 2000).

Otázky v rozhovoru se nejvíce vztahovaly k osobním zkušenostem nebo k chování dotazované osoby. Také byly použity otázky zaměřené na znalosti, které měly objasnit, co respondent skutečné zná. Dále byly položeny otázky, které byly zaměřené na porozumění kognitivním a orientačním procesům respondenta (Hendl 2005). Pořadí jednotlivých otázek $\checkmark$ rozhovoru odpovídalo pravidlům, která jsou daná pro využívání této techniky. $V$ průběhu rozhovoru byly pokládány další otázky, které vedly k lepšímu pochopení otázky nebo k prohloubení odpovědi (Švaříček \& Šed'ová 2007, Hendl 2005, Skutil et al. 2011).

Prostřednictvím rozhovorů jsme především chtěli zjistit, jak respondenti vnímají pojem postoj a zda jsou schopni ho definovat. $V$ další fázi jsme se dotazovali, jestli si myslí, že se jejich výuka zaměřuje na rozvoj postojů. $V$ průběhu výzkumu se dále ukázalo jako

\footnotetext{
${ }^{3}$ Pfligersdorffer, G. (1993): Relativnost ekologického poznání pro jednání, které je v souladu s životním prostředím. In: Výchova v rodine a škole. Sborník. Slovenská akadémia vied, Bratislava, 6677.
} 
účelné zabývat se vztahem rodiny a školy z hlediska rozvoje environmentálních postojů a také vlivem zavádění RVP/ŠVP na rozvoj postojů. $V$ této souvislosti jsme se zaměřili na environmentální postoje, které by dle Rámcového vzdělávacího programu pro základní vzdělávání (Výzkumný ústav pedagogický 2007) mělo průřezové téma environmentální výchova u žáků rozvíjet. $Z$ tohoto dokumentu jsme vycházeli i pres jeho kritiku z hlediska zpracování environmentální výchovy (viz např. Činčera 2009) nebot' jednotlivé oblasti, týkající se rozvoje postojů, jsou definovány $v$ obecné rovině a jsou vzájemně provázané, čímž zasahují co celého (širokého) spektra environmentální výchovy. Dalším důvodem pro tuto volbu byla závaznost tohoto dokumentu a skutečnost, že většina učitelů postupuje podle starší verze, vzhledem $\mathrm{k}$ tomu, že Doporučené očekávané výstupy prưřezového tématu Environmentální výchova (Pastorová et al. 2011) nejsou zatím mezi učiteli dostatečně rozšířené.

Při analýze získaných rozhovorů jsme postupovali následujícím způsobem. V první fázi byla provedena doslovná transkripce všech rozhovorů. Pro lepší organizaci a práci s daty byla provedena jejich segmentace, čímž jsme získali analytické jednotky (blíže k metodě viz Skutil et al. 2011). Tuto část vyhodnocování prováděl jeden z autorů. Vyhodnocování získaných analytických jednotek pomocí kódování, poznámkování a kategorizace prováděl každý autor samostatně. Závěrečná interpretace dat je výsledkem společné diskuze obou autorů nad zjištěnými výsledky.

\section{Vyhodnocení výsledků}

Při vyhodnocování výsledků byly analytické jednotky roztříděny podle toho, na kterou z výzkumných otázek podávají odpověd'.

Do první kategorie tak byly zařazeny výroky zaměřené na porozumění pojmu postoj a jeho odlišení od príbuzných pojmů (názor, hodnota, př́ípadně zájem). Výsledky ukázaly, že řada respondentů nedovede vysvětlit, co si pod pojmem postoj představuje ( $v$ mnoha prípadech se cítili zaskočeni).

Část respondentů pojem postoj dokázala vlastními slovy vysvětlit, přestože $\checkmark$ některých př́padech jej zaměňují s jinými pojmy (jako např. chování, zájem či dovednost) - např. respondentka G: "To je vlastně podle mě jak se fakticky chová“ nebo respondentka A: „Postoj je nějaká dovednost, kterou děti převádí do běžného života".

Respondent E chápe postoj jako „konkrétní projev chování v konkrétní situaci“ (je ovšem otázka, zda projev chování vznikl v důsledku zastávaného postoje), ale dále tuto definici rozvíjí: "Nejen že ví, ale je schopen řešit problémy, které kolem sebe vidí, zajímá se a je schopen reagovat“.

Poměrně dobré porozumění bylo zaznamenáno $v$ př́padě vztahu mezi pojmy hodnota a názor - např. respondentka J uvádí: "Hodnota je něco, podle čeho si člověk vytváří hodnotový systém a je asi stálejší než názor“.

Druhá kategorie výroků se vztahovala k rozvoji postojů ve výuce. Zajímalo nás především, zda jsou postoje rozvíjeny cíleně a jaký význam jim respondenti přikládají. Téměř všichni respondenti se shoduji na tom, že postoje ve výuce rozvíjejí, zároveň však uvádějí, že tento rozvoj většinou není cílený. Při rozvoji se zaměřují na použitelnost nově získaných postojů v běžném životě. Velmi často také uváděli, že úspěšnost rozvoje postojů závisí na tom, jak náročná změna chování nebo jaká míra nepohodlí vyplývá z přijetí daného postoje. Toto zjištění odpovídá výsledkům výzkumů dalších autorů - např. Franěk (2008), Winter \& Koger (2009) aj. 
Respondentka H uvedla, že: „... namísto prímého předávání postojů vytvář́m podmínky pro to, aby si žáci postoje rozvíjeli sami na základě získaných poznatkü a vyvozovali sami závěry". Je samozřejmě diskutabilní, zda takový př́stup Ize považovat za cílený rozvoj postojů. Také respondent $F$ se sice cíleně nezaměřuje na rozvoj postojů, ale prostřednictvím diskuzí vytváŕí prostor pro jejich rozvoj: „....chci, aby děti věděly, že každá věc má dvě strany“. $Z$ výpovědí některých respondentů také vyplynulo, že $k$ rozvoji postojů přispívají mimo jiné i prostřednictvím osobního vzoru.

Tento př́stup se objevil také $v$ odpovědi respondentky $D$, která na otázku, zda ve výuce rozvíjí postoje, uvedla, že: "Tak řekla bych, že tou výukou asi ne. Ty postoje se odvijejí hodně i jako skrytě, okrajově, jak ta výuka probíhá nebo třeba tím, jak já vyjadřuju, jakej mám k čemu postoj, když o něčem mluvím, tak o tom mluvím nějak zapáleně. Dávám najevo své postoje, tak na nějaké děti to může působit. Ale z povahy mého předmětu, který je naukový, se těma postojema teda málo zabývám". $\mathrm{V}$ tomto př́padě bylo ovšem velmi diskutabilní, zda Ize uvedený př́stup považovat za rozvoj postojů. Vzhledem $\mathrm{k}$ tomu, že respondentka sama tento př́stup za rozvoj postojů nepovažuje, jsme však tento př́stup za rozvoj postojů ve výuce nepovažovali.

Třetí kategorie výroků byla zaměřena na rozvoj environmentálních postojů na konkrétní škole, kde daný koordinátor EVVO působí. Vedle př́mé práce daného pedagoga byly zahrnuty $i$ aktivity ostatních pedagogů na škole, o kterých měl koordinátor přehled. $Z$ rozhovorů nepř́mo vyplynulo, že většina koordinátorů nemá přehled o environmentálních aktivitách, které se odehrávají ve vyučovacích hodinách jejich kolegů.

Celkově je ovšem škála témat rozvíjejících environmentální postoje velmi široká: ochrana přirody, změna klimatu, nakládání s odpadem, zdravý životní styl, význam biodiverzity, prírodní zdroje, šetrné nakupování, klasická ekologie, průmysl, vnější geologické děje, pralesy, dezertifikace, dětská práce apod. Je tedy zřejmé, že rozsah témat zasahuje do prírodovědných i společenskovědních předmětů, na problémy je nazíráno na různé měřítkové úrovni a často je kladen důraz na skutečnosti pro žáky lépe uchopitelné (co vidí ve svém okolí a mohou to ovlivnit). Většina respondentů se shoduje na potřebě rozvíjet u žáka zájem o místo, kde žije.

Respondenti uváděli prakticky všechny prostředky environmentální výchovy zmiňované Činčerou (2007). Jedná se o didaktické a simulační hry, terénní výuku včetně badatelsky orientované (na tento přístup kladla značná část respondentů důraz), praktické projekty (velmi často zakončené výstavkou apod.), filmy s následnou diskuzí, setkání s odborníky (besedy, přednášky) a velmi často je zmiňována práce na školní zahradě. Ve dvou případech zaznělo, že na rozvoji environmentální postojů se pozitivně podílí školní respektive žákovský parlament. Prostředky tedy můžeme rozdělit podle toho, $v$ jakém prostředí jsou použity (přímo ve školní budově $\times$ mimo ni - např. $v$ terénu, ve strediscích EV) a kdo je zajištuje (učitel $\times$ externí lektor). Výše uvedené činnosti můžeme vesměs chápat jako intelektově náročnější a zaměřené na rozvoj vyšších úrovní Bloomovy taxonomie vzdělávacích cílů (Bloom 1956, Andrson \& Krathwohl 2001), které jsou pro vhodné pro rozvoj postojů (Petty 1996).

Do čtvrté kategorie byly zařazeny výroky, které podávaly odpověd’ na otázku: Jak hodnotíte zavedení RVP/ŠVP z hlediska vlivu na rozvoj postojů? Mezi respondenty Ize najít jak učitele, kteří se podíleli na tvorbě ŠVP, kde pracovali i s oblastí postojů, které má dle RVP rozvíjet environmentální výuka (respondentky $A, G, J$ ), tak učitele, kteří se na vytváření ŠVP nepodíleli (respondenti C, F), protože na danou školu nastoupili až v době, kdy již škola měla vypracovaný svůj ŠVP. Respondenti, kteří učili i před zavedením RVP/ŠVP, se svou výukou zaměřovali na rozvoj postojů i před jejich zavedením a nevnímali žádný větší rozdíl 
V rozvoji postojů po zavedení RVP/ŠVP. V rozhovorech bylo velmi často uváděno "tyhle věci se dělaly i před tím, akorát je nikdo takhle nepojmenovával" (respondent $\mathrm{H}$, velmi podobně odpověděli i respondentky $A, I, J)$. Na druhou stranu však respondent $E$ uvedl, že při přípravě environmentálních aktivit využívá doporučené očekávané výstupy environmentální výchovy (viz Pastorová et al. 2011). Z jeho odpovědí bylo zjištěno, že na formování postojů klade veliký důraz, což se projevuje v kvalitě jím připravovaných aktivit.

Poslední kategorie výroků se vztahovala k vzájemnému přenosu environmentálních postojů $z$ žáků na rodiče a naopak. Většina respondentů zaznamenala přenos ve škole získaných postojů (popř. informací) od žáků k rodině. Respondentka A dokonce uvedla: „Taky máme problém s tím, že děti od rodičů nemaji žádné základy. My vidíme, když se nám podaři zkultivovat děti i pres jejich odpor, tak pak vidíme, jak to přenesou na tu rodinu. Ale obráceně, že by dítě přišlo s nějakými environmentálními postoji nebo dovednostmi z rodiny - to nepřijde.". Pouze respondentka D si myslí, že postoje mají formovat rodiče a ne škola. Většina respondentů se shoduje na tom, že rozvoj postojů prostřednictvím rodiny závisí především na její funkčnosti (některé rodiny řeší úplně jiné problémy), že jsou mezi rodinami veliké rozdíly a na každou se musí nahlížet individuálně. Toto tvrzení velmi pěkně shrnuje respondent E: „Jsou velký rozdíly mezi těma dětma. Jsou rodiče, který jsou nadšení z toho, že jsme na stejné lodi jako oni, a že pokračujeme $v$ tom čemu je oni učili. Pak jsou rodiče, který jsou překvapení, že to je jinak než si mysleli, ale jsou vstříný k tomu, že jim děti přinášejí tyto informace domů. Pak jsou ale rodiče, který jaksi jsou toho typu - vy jdete dneska ven, to se zase neučíte, tak to nemusís chodit do školy a půjdeš se mnou dneska nakupovat. J sou to velké rozdíly. " $Z$ analýzy rozhovorů nám vyplynuly tři základní elementy, které ovlivňují postoje žáků. Kromě výše zmíněné školy a rodiny hrají důležitou roli $i$ kamarádi, se kterými se žák stýká (srovnej s Chawla 1999, Eagels \& Demare 1999, Kulhavý 2009 - viz výše).

\section{Analýza výsledků}

$\mathrm{Na}$ základě výše komentovaných skutečností můžeme respondenty rozdělit do několika základních skupin, a to podle čtyř základních kritérií:

- porozumění pojmu postoj,

- odlišení postojů od názoru, zájmu a hodnoty,

- reálný rozvoj postojů ve výuce a

- zahrnutí postojů do prípravy hodiny resp. očekávaných výstupů.

Na základě těchto kritérií bychom mohli respondenty rozdělit až do 16 skupin, které jsou uvedeny v príloze č. 2. Mnohé kombinace však připadají v úvahu pouze teoreticky. Níže uvádíme reálně zaznamenané skupiny vytvořené na základě analýzy a porovnání všech odpovědí, které respondent uvedl $v$ průběhu celého rozhovoru. Jednotlivá tvrzení respondentů byla ověřována pomocí dalších odpovědí na doplňující otázky. Respondenty našeho výzkumu tak můžeme rozdělit do těchto kategorií:

1. Respondent rozumí obsahu pojmu postoj a vnímá rozdíly mezi př́buznými pojmy. Ve výuce postoje rozvíjí a cíleně se zaměřuje na jejich rozvoj.

Do této kategorie spadá pouze respondent $\mathrm{E}$, který v porovnání $\mathrm{s}$ ostatními respondenty také využíval nejvíce rozličných forem a metod, jimiž u žáků rozvíjí environmentální postoje. 
2. Respondent nerozumí obsahu pojmu postoj, ale vnímá rozdíl od ostatních pojmů. Postoje ve výuce rozvíjí, ale nikoliv cíleně.

Nejpočetnější kategorie, do které spadá šest respondentů, které jsme pracovně označili jako „intuitivní učitele". Fakt, že postoje ve své výuce rozvíjejí, vyplývá i z dalších jejich odpovědí $v$ rámci celého rozhovoru (uváděli konkrétní aktivity směřující k rozvoji postojů).

3. Respondent nerozumí obsahu pojmu postoj, ani nevnímá rozdíl od ostatních pojmů. Postoje ve výuce rozvíjí, ale nikoliv cíleně.

Tato kategorie je velmi podobná kategorii předchozí. Uvedeným kritérím odpovídaly odpovědi respondentky $\mathrm{H}$, která uvedla, že žákům nepředkládá "hotové“ postoje, ale vytváŕi jim prostor proto, aby si sami na základě jim dodaných informací vytvořili vlastní postoj. Podobně jako $v$ předchozím prípadě dochází $\mathrm{k}$ rozvoji postojů díky intuitivnímu př́stupu učitele. Je ovšem diskutabilní, zda tento přístup můžeme považovat za cílený rozvoj postojů.

4. Respondent nerozumí obsahu pojmu postoj, ani nevnímá rozdíl od ostatních pojmů. Ve výuce ovšem postoje rozvíjí a tvrdí, že na jejich rozvoj se zaměřuje cíleně.

Přestože tato kombinace působí spíše nereálně, z rozhovoru skutečně vyplynulo, že výukové metody, které respondentka (jednalo se o respondentku C) uvedla, jsou zaměřeny na rozvoj postojů, přestože je respondentka takto nenazývá. Respondentka byla otázkou velmi zaskočena, což částečně může vysvětlit její odpovědi. Avšak jako většina respondentů spojovala pojem postoj s chováním.

5. Respondent nerozumí obsahu pojmu postoj, ale vnímá rozdíl od ostatních pojmů. Postoje ve výuce nerozvíjí, ani se na jejich rozvoj nezaměřuje cíleně.

Do této kategorie byla zařazena respondentka $D$, jejiž odpovědi ovšem byly značně rozporuplné a do určité míry si protiřečily. Nicméně z jejích odpovědí vyplývá, že postoje ve výuce cíleně nerozvijí, i když tvrdí, že je považuje za velmi důležitou součást školního vzdělávání.

\section{Diskuze}

Výsledky provedeného výzkumu je třeba hodnotit $s$ vědomím značně omezené vypovídací hodnoty získaných dat. Jednalo se pouze o menší výzkumnou sondu, polostrukturované rozhovory byly provedeny $\mathrm{s}$ velmi úzkou skupinou respondentů. Vyhodnocování rozhovorů bylo z důvodu větší objektivity prováděno dvěma výzkumníky, přesto mohlo dojít k určitému zkreslení, nepochopení či nepřesné interpretaci některých výpovědí.

Bylo např́klad velmi obtížné vyhodnotit, které odpovědi Ize považovat za "správnou" definici postojů (a dalších príbuzných pojmů), a které nikoliv. Tyto pojmy mohou být samozřejmě do určité míry chápány i odlišně ( $a$ pritom ne nesprávně) v porovnání $s$ tím, jak je definují autoři, z jejichž prací jsme vycházeli. Proto jsme byli při hodnocení "správnosti" odpovědí respondentů postupovali dosti volně a namísto doslovné definice jsme očekávali pouze základní porozumění pojmům.

Podobně nejednoznačné bylo najít hranici mezi učiteli, kteři svou výukou přispívají k rozvoji postojů, a těmi, kteří k němu nepřispívají. 
I přes uvedené limity výzkumu přináší provedené šetření některá zajímavá zjištění, která mohou být podnětem $\mathrm{k}$ dalšímu výzkumu. Nejvýznamnější z nich shrnujeme v závěru tohoto príspěvku.

\section{Závěr}

I přes svůj omezený rozsah přináší provedený výzkum některá zajímavá zjištění. Výsledky mimo jiné poukazují na skutečnost, že řada respondentů nedovede uspokojivě vysvětlit obsahovou náplň pojmu postoj, obvykle však vnímají rozdíly od př́buzných pojmů a téměř všichni respondenti postoje ve výuce rozvíjejí. Rozvoj však většinou není cílený, postoje jsou ve výuce rozvíjeny intuitivně, aniž by byly takto nazývány. Tento přístup byl zaznamenán u větší části respondentů. Pouze jeden z respondentů dovedl nejen pojem postoje dobře definovat a odlišit od př́buzných pojmů, ale zároveň se také na jejich rozvoj ve výuce cíleně zaměřuje.

Škála témat a prostředků rozvíjejících environmentální postoje je velmi široká a respondenti často kladli důraz na skutečnosti, které jsou pro žáky dobře uchopitelné (co vidí ve svém okolí a mohou to ovlivnit). Většina respondentů se shoduje na potřebě rozvíjet u žáka zájem o místo, kde žije, a vštípit žákům myšlenku „mysli globálně - jednej lokálně".

Respondenti uváděli širokou škálu prostředků environmentální výchovy, zdůrazňovali hlavně terénní výuku včetně badatelsky orientované. Pokud škola disponuje školní zahradou, uváděli ji respondenti jako vhodné místo pro realizaci výuky, jejímž cílem je (nejen) osvojování environmentálních postojů. Celkově Ize říci, že činnosti vedoucí k osvojování postojů jsou kognitivně náročnější a zaměřují se na rozvoj vyšších úrovní Bloomovy taxonomie vzdělávacích cílů. Ukázalo se také, že ( $v$ souladu například s Kalhousem a Obstem et al. 2002) má pro rozvoj postojů velký význam osobnost učitele a několik respondentů uvedlo, že postoje u svých žáků rozvíjejí prostřednictvím osobního vzoru. Většina respondentů se domnívá, že zavedení RVP/ŠVP př́liš neovlivnilo výuku zaměřenou na formování postojů, nebot' se domnívají, že takto orientovaná výuka probíhala i před zavedením RVP/ŠVP, pouze nebyla takto pojmenovávána.

Většina respondentů také zmínila přenos postojů (popř. informací) získaných ve škole směrem od žáků k rodině. Míra tohoto přenosu je však individuální.

Celkově Ize říci, že postoje jsou jedním z důležitých cílů environmentální výchovy a jejich vymezení by měla být věnována větší pozornost. Většinou intuitivní uchopení tohoto pojmu učiteli svědčí o tom, že pro rozvíjení postojů ve výuce neexistuje pevný rámec. Rozvoj postojů ve výuce je zároveň spojen s řadou problémů, mezi něž patří např. obtižná možnost jejich hodnocení, častá disproporce mezi deklarovanými a skutečnými postoji, neexistence jediného "správného prístupu" (zejména, ale nejen, v prípadě kontroverzních témat) apod. Zmapování pestré škály přístupů $\mathrm{k}$ těmto otázkám $v$ aktuální školní praxi představuje zajímavou výzvu pro další výzkum v této oblasti.

\section{Seznam použité literatury}

- Anderson, L. W., \& Krathwohl, D. R. (Eds.). (2001). A Taxonomy for Learning, Teaching and Assessing. New York: Longman.

- Bechtel, R. B., \& Churchman, A (2002). Handbook of environmental psychology. New York: John Wiley \& Sons, Inc. 
- Bezouška, A., \& Činčera, J. (2007). Vliv environmentální profilace středních škol na proenvironmentální postoje a jednání studentů. Envigogika, II/3.

- Bloom, B., S. et al. (1956). Taxonomy of Educational Objektives: The classification of educational goals. Handbook I: Cognitive Domain. New York: David McKay Company.

- Clayton, S. (2003). Environmental identity: A conceptual and an operational definition. In S. Clayton \& S. Opotow (Eds.), Identity and the Natural Environment Cambridge, s. 45-65.

- Čáp, J., \& Mareš, P. (2001). Psychologie pro učitele. Praha: Portál.

- Činčera, J. (2009). Analýza průřezového tématu Environmentální výchova v Rámcovém vzdělávacím programu pro základní vzdělávání. Envigogika, IV/1.

- Činčera, J. (2007). Environmentální výchova: od cílů k prostředkům. Brno: Paido.

- Činčera, J. (2013a). Metodika pro hodnocení environmentální výchovy pro předškolní a mladší školní věk. Envigogika, VII/5.

- Činčera, J. (2013b). Metodika pro hodnocení environmentální výchovy pro starší školní věk a střední školy. Envigogika, VII/5.

- Činčera, J. (2013c). Metodika pro hodnocení environmentální výchovy pro dospělé účastníky. Envigogika, VII/5.

- Činčera, J., \& Štěpánek, P. (2007). Výzkum ekologické gramotnosti studentů středních odborných škol. Envigogika, II/1.

- Daniš, P. (2013). Nové vymezení environmentální gramotnosti a návrh na její mezinárodní testování v PISA 2015. Envigogika, 8(3).

DOI : http://dx.doi.org/10.14712/18023061.385

- Dimnopoulos, D., \& Pantis, J. (2003). Knowledge and Attitudes Regarding Sea Turtle in Elementary Students on Zakynthos, Greece. The Journal of Environmental Education, 34(3), 30-38.

- Dobiášová, K. (2008). Rasové postoje u dětí. Diplomová práce. Brno: Masarykova univerzita, Pedagogická fakulta.

- Dunlap, R. E., Van Liere, K. D., Mertig A. G., Jones, R. E. (2000). Measuring endorsement of the New Ecological Paradigm: a revised NEP scale. The Journal of Social I ssues, 56(3), 425-442.

- Dutcher, D., Finley, J., Luloff, A., \& Johnson, J. (2007). Connectivity with nature as a measure of environmental values. Environment and Behavior, 39, 474- 493.

- Eagels, P. F., \&J., Demare, R. (1999). Factors Influencing Children's Environmental Attitudes. Journal of Environmental Education, 30, 33-37.

- Ferjenčík, J. (2000). Úvod do metodologie psychologického výzkumu: Jak zkoumat lidskou duši. Praha: Portál. 
- Finnová, M. (2010). Environmentální postoje na venkově a ve městě (Př́padová studie respondentek z obce Hostouñ a hlavního města Prahy). Diplomová práce. Praha: Univerzita Karlova v Praze, Fakulta humanitních studií.

- Fontana, D. (1997). Psychologie ve školní praxi. Praha: Portál.

- Franěk, M. (2008). Postoje ke tř́́dění a recyklaci odpadu determinované vztahem k prírodě a osobnostními rysy. Psychologie v ekonomické praxi, 43(1-2), 11-25.

- Franěk, M. (2012). Nature Relatedness Scale. Český překlad škály měřící spojení s př́rodou. Envigogika, VI/2.

- Geist, B. (2000). Psychologický slovník, Praha: Vodnáŕ.

- Guagnano, G., \& Markee, N. (1995). Regional differences in the sociodemographic determinants of environmental concern. Population and Environment. A J ournal of Interdisciplinary Studies, (17), 135-149.

- Hartl, P., \& Hartlová, H. (2000). Psychologický slovník. Praha: Portál.

- Hayesová, N. (2013). Základy sociální psychologie. Praha: Portál.

- Hendl, J. (2005). Kvalitativní výzkum: základní metody a praxe. Praha: Portál,.

- Holíková, M. (2013): Environmentální postoje česko-němockého pohraničí v Krušných horách - př́padová studie lokální identity obyvatel města Hora Svaté Kateřiny. Bakalářská práce. Brno: Masarykova univerzita, Fakulta sociálních studií.

- Hromádka, Z. (2008). Vztahy mezi vědomosti, postoji a skutečným jednáním u žáků druhého stupně základní školy v rámci environmentální výchovy. Pedagogická orientace, 18(1), 22-33.

- Chawla, L. (1999): Life path into effective environmental action. The Journal of Environmental Education. 31(1), 15-26.J agers, S.C. \& Matti, S. (2010). Ecological Citizens: Identifying Values and Beliefs that Support Individual Environmental Responsibility among Swedes. Sustainability, 2(4) 1055-1079.

- Jandourek, J. (2001). Sociologický slovník. Praha: Portál.

- Kalhoust, Z. \& Obst, O. et al. (2002). Školní didaktika. Praha: Portál.

- Kilbourne, W, E., \& Polonsky, M, J. (2005). Environmental Attitudes and their Relation to the Dominant Social Paradigm Among University Students In New Zealand and Australia. Australasian Marketing Journal, 13(2), 37-48.

- Klopfer, L. E. (1976). A Structure for the Affective Domain in Relation to Science Education. Science Education, 60, 299-312.

- Krajhanzl, J. (2010): Charakteristika osobního vztahu k prírodě - Úvod do teorie a pojmosloví. Disertační práce. Prah: Univerzita Karlova v Praze, Filozofická fakulta.

- Krajhanzl, J. (2009). Exkurz do osobní charakteristiky vztahu k prírodě. In: Člověk + príroda $=$ udržitelnost? Zelený kruh, Praha, s. 2-7.

- Kubiatko, M., Mrázková, K., \& Janko, T. (2011). Postoje žáků 2. stupně základních škol k vyučovacímu předmětu zeměpis. Pedagogika, 61(3), 257-270. 
- Kulhavý, V. (2009). Zážitky významné pro formování vztahu člověka k přírodě shrnutí dosavadních poznatků. In: Člověk + prríroda = udržitelnost? Zelený kruh, Praha, s. 90-99.

- Kurz, T., Linden, M., Sheehy, N. (2007). Attitudial and Community Influences on Participation in New Curbside Recycling I nitiatives in North I reland. Environment and Behavior, 39(3) 367-391.

- Lindstrom, M., \& J ohnsson, P. (2003). Environmental concern, self-concept and defense style: A study of Agenda 21 process in Swedish municipality. Environmental Education Research, 9(1), 51-66.

- Matějček, T. (2010). Environmentální postoje budoucích učitelů zeměpisu. Informace ČGS, 29(2), 13-29.

- Matějček, T., \& Bartoš, J. (2012). Environmentální gramotnost učitelů a studentů učitelství. Envigogika, VII/2.

- Mayer, S. F., \& Frantz, C. M. (2004). The connectedness to nature scale: A measure of individuals' feeling in community with nature. Journal of Environmental Psychology, 24, 503-515.

- Niemierko, B. (1979). Taksonomie celów wychowania. Kwartalnik pedagogiczny, 24(2), 66-67.

- Nisbet, E. K. L., Zelenski, J. M., \& Murphy, S. A. (2009). The Nature Relatedness Scale: Linking individuals' connection with nature to environmental concern and behavior. Environment and Behavior, 41, 715-740.

- Pastorová et al.: (2011). Doporučené očekávané výstupy: Environmentální výchova v základním vzdělávání - metodická podpora. vúP, Praha. 28 s. Dostupný z: http://www.vuppraha.cz, [cit. 5. června 2015]

- Petty, G. (1996). Moderní vyučování: praktická příručka. Praha: Portál.

- Powell, R. B., Stern, M. J., Krohn, B. D., Ardoin, N. (2011). Development and validation of scales to measure environmental responsibility, character development, and attitudes toward school. Environmental Education Research, 17(1) 91-111.

- Průcha, J., Waltrová, E., \& Mareš, J. (1998). Pedagogický slovník. Praha: Portál.

- Rickinson, M. (2001). Learners and Learning in Environmental Education: a critical review of the evidence. Environmental Education Research, 7(3), 207-320.

- Řehan, V., \& Cakirpaloglu, P. (2000). Sociální status a hodnotová orientace mladé generace. Českoslovenká psychologie, 44(3), 202-215.

- Řezáč, J. (1998). Sociální psychologie, Brno: Paido.

- Said, A. M., Yahaya, N., Ahmadum, F. (2007). Environmental comprehension and participation of Malaysian secondary school students, Environmental Education Research, 13(1), 17-31. 
- Senčík, J. (2009). Postoje k životnímu prostředí. Diplomová práce. Praha: Univerzita Karlova v Praze, Př́rodovědecká fakulta.

- Schmutzlerová, L., \& Bílek, M. (2010). Jak hodnotí čeští patnáctiletí žáci základních škol a studenti víceletých gymnázií environmentální problémy. Envigogika, V/2.

- Schultz, P. W. (2001). The structure of environmental concern: Concern for self, other people, and the biosphere. Journal of Environmental Psychology, 21, 327339.

- Skutil, M., et al. (2011). Základy pedagogicko-psychologického výzkumu pro studenty učitelství. Praha: Portál.

- Slaměník, I., \& Výrost, J. (2008): Sociální psychologie. Praha: Grada.

- Švaříček, R., \& Šed’ová, K., a kol. (2007). Kvalitativní výzkum v pedagogických vědách. Praha: Portál.

- Tbilisi (1978): Tbilisi conference declaration. Dostupné z http://www.gdrc.org/uem/ee/EE-Tbilisi_1977.pdf, [cit. 5. června 2015]

- Tuncer, G., Ertepinar, H., Tekkaya, S., Sungur, S. (2005). Environmentajl attitudes of young people in Turkey: effects of school type and tender. Environmental Education Research, 11(2), 215-233.

- Tuncer, G., Sungur, S., Tekkaya, S., Ertepinar, H. (2004). Environmental attitudes of the 6th grade students from rural and urban areas: A case study for Ankara. Hacettepe Üniversitesi Egitim Fakültesi Dergisi, 26, 167-175.

- ÚIV (2006). Koncepce prírodovědné gramotnosti ve výzkumu PISA 2006. Ústav pro informace ve vzdělávání, Praha. Dostupné z http://csicr.cz/getattachment/cz/O-nas/Mezinarodni-setreni-archiv/PISA/PISA2006/Koncepce-prirod-gramot-v-PISA-2006.pdf

- Výzkumný ústav pedagogický: (2007). Rámcový vzdělávací program pro základní vzdělávání, vúP, Praha, 126 s. Dostupný z: http://www.vuppraha.cz, [cit. 5. června 2015]

- Winter, D. D. N., \& Koger, S. M. (2009): Psychologie environmentálních problémů. Praha: Portál. 
Př́loha č. 1

Základní charakteristika respondentů

\begin{tabular}{|c|c|c|c|c|}
\hline Označení & Pohlaví & $\begin{array}{l}\text { Vystudovaná } \\
\text { aprobace }\end{array}$ & $\begin{array}{l}\text { Předměty, které } \\
\text { nyní učí }\end{array}$ & $\begin{array}{l}\text { Absolvoval } \\
\text { kurz EVVO? }\end{array}$ \\
\hline $\begin{array}{l}\text { Respondent } \\
\text { „A“ }\end{array}$ & Žena & $\begin{array}{l}\text { Biologie, } \\
\text { matematika }\end{array}$ & $\begin{array}{l}\text { Přírodopis, } \\
\text { matematika, } \\
\text { občanská výchova }\end{array}$ & Ano \\
\hline $\begin{array}{l}\text { Respondent } \\
\text { „B“ }\end{array}$ & Žena & $\begin{array}{l}\text { Přírodopis, základy } \\
\text { zemědělské výchovy }\end{array}$ & $\begin{array}{l}\text { Přírodopis, ekologický } \\
\text { seminář }\end{array}$ & Ano \\
\hline $\begin{array}{l}\text { Respondent } \\
{ }_{\text {"C" }}\end{array}$ & Žena & $\begin{array}{l}\text { Český jazyk, } \\
\text { občanská výchova }\end{array}$ & $\begin{array}{l}\text { Český jazyk, } \\
\text { občanský výchova, } \\
\text { ekologická výchova }\end{array}$ & Ano \\
\hline $\begin{array}{l}\text { Respondent } \\
\text { "D“ }\end{array}$ & Žena & $\begin{array}{l}\text { Biologie, speciální } \\
\text { pedagogika }\end{array}$ & Přírodopis & Ano \\
\hline $\begin{array}{l}\text { Respondent } \\
\text { "E“ }\end{array}$ & Muž & $\begin{array}{l}\text { Matematika, } \\
\text { biologie }\end{array}$ & $\begin{array}{l}\text { Přírodopis, } \\
\text { matematika, }\end{array}$ & Ano \\
\hline $\begin{array}{l}\text { Respondent } \\
\text { "F“ }\end{array}$ & Muž & Geografie, biologie & $\begin{array}{l}\text { přírodopis, zeměpis, } \\
\text { tělesná výchova }\end{array}$ & Ano \\
\hline $\begin{array}{l}\text { Respondent } \\
\text { "G" }\end{array}$ & Žena & $\begin{array}{l}\text { Speciální } \\
\text { pedagogika }\end{array}$ & $\begin{array}{l}\text { český jazyk, } \\
\text { matematika, } \\
\text { přírodopis }\end{array}$ & Ano \\
\hline $\begin{array}{l}\text { Respondent } \\
\text { "H“ }\end{array}$ & Žena & $\begin{array}{l}\text { Biologie, } \\
\text { matematika }\end{array}$ & biologie, matematika & Ano \\
\hline $\begin{array}{l}\text { Respondent } \\
\text { "I“" }\end{array}$ & Žena & Geografie, biologie & $\begin{array}{l}\text { přírodopis, biologie, } \\
\text { výchova k občanství }\end{array}$ & $\mathrm{Ne}$ \\
\hline $\begin{array}{l}\text { Respondent } \\
\text { "J" }\end{array}$ & Žena & Př́rodopis, chemie & přírodopis, chemie & $\mathrm{Ne}$ \\
\hline
\end{tabular}

Všichni respondenti učí na základních školách $v$ Praze nebo Středočeském kraji. Výzkum byl proveden $v$ roce 2014. 


\section{Př́loha č. 2}

Teoreticky možné rozdělení respondentů podle kritérií

\begin{tabular}{|c|c|c|c|c|c|}
\hline $\begin{array}{l}\text { označení } \\
\text { skupiny v } \\
\text { textu }\end{array}$ & $\begin{array}{l}\text { porozumění } \\
\text { pojmu postoj }\end{array}$ & $\begin{array}{l}\text { odlišení od } \\
\text { příbuzných } \\
\text { pojmů }\end{array}$ & $\begin{array}{l}\text { reálný } \\
\text { rozvoj } \\
\text { postojů ve } \\
\text { výuce }\end{array}$ & $\begin{array}{l}\text { zahrnutí } \\
\text { postojů do } \\
\text { prípravy } \\
\text { hodiny }\end{array}$ & $\begin{array}{l}\text { zařazení } \\
\text { respondenti }\end{array}$ \\
\hline \multirow[t]{9}{*}{ 1) } & ano & ano & ano & ano & $E$ \\
\hline & ano & ano & ano & ne & \\
\hline & ano & ano & ne & ano & \\
\hline & ano & ano & ne & ne & \\
\hline & ano & ne & ano & ano & \\
\hline & ano & ne & ano & ne & \\
\hline & ano & ne & ne & ano & \\
\hline & ano & ne & ne & ne & \\
\hline & ne & ano & ano & ano & \\
\hline \multirow[t]{2}{*}{ 2) } & ne & ano & ano & ne & $A, B, F, G, I, J$ \\
\hline & ne & ano & ne & ano & \\
\hline 5) & ne & ano & ne & ne & $\mathrm{D}$ \\
\hline 4) & ne & ne & ano & ano & C \\
\hline \multirow[t]{3}{*}{ 3) } & ne & ne & ano & ne & $\mathrm{H}$ \\
\hline & ne & ne & ne & ano & \\
\hline & ne & ne & ne & ne & \\
\hline
\end{tabular}

Mgr. Jan Bartoš, Přírodovědecká fakulta UK v Praze, jan.bartos8@gmail.com,

RNDr. Tomáš Matějček, Ph.D., Přírodovědecká fakulta UK v Praze, Přírodovědecká fakulta UJ EP v Ústí nad Labem, tomasmat@seznam.cz 